Article

\title{
Discovery of Two New Sorbicillinoids by Overexpression of the Global Regulator LaeA in a Marine-Derived Fungus Penicillium dipodomyis YJ-11
}

\author{
Jing Yu ${ }^{1}{ }^{\oplus}$, Huan Han ${ }^{1}$, Xianyan Zhang ${ }^{1}$, Chuanteng Ma ${ }^{1} \oplus$, Chunxiao Sun ${ }^{1}$, Qian Che ${ }^{1}$, \\ Qianqun Gu ${ }^{1}$, Tianjiao Zhu ${ }^{1,2} \mathbb{D}$, Guojian Zhang ${ }^{1,2}$ and Dehai Li ${ }^{1,2, *(D)}$ \\ 1 Key Laboratory of Marine Drugs, Chinese Ministry of Education, School of Medicine and Pharmacy, \\ Ocean University of China, Qingdao 266003, China \\ 2 Laboratory for Marine Drugs and Bioproducts, Pilot National Laboratory for Marine Science and \\ Technology (Qingdao), Qingdao 266237, China \\ * Correspondence: dehaili@ouc.edu.cn; Tel.: +86-532-8203-1619; Fax: +86-532-8203-3054
}

Received: 28 May 2019; Accepted: 26 July 2019; Published: 28 July 2019

\begin{abstract}
Overexpression of the global regulator LaeA in a marine-derived fungal strain of Penicillium dipodomyis YJ-11 induced obvious morphological changes and metabolic variations. Further chemical investigation of the mutant strain afforded a series of sorbicillinoids including two new ones named 10,11-dihydrobislongiquinolide (1) and 10,11,16,17-tetrahydrobislongiquinolide (2), as well as four known analogues, bislongiquinolide (3), 16,17-dihydrobislongiquinolide (4), sohirnone A (5), and $2^{\prime}, 3^{\prime}$-dihydrosorbicillin (6). The results support that the global regulator LaeA is a useful tool in activating silent gene clusters in Penicillium strains to obtain previously undiscovered compounds.
\end{abstract}

Keywords: genome mining; global regulator; LaeA; overexpression; Penicillium dipodomyis; sorbicillinoids

\section{Introduction}

Filamentous fungi have proven to be important sources of bioactive natural products for development of new drug leads. As the traditional approach (cultivation of microorganisms, chemical extraction of the produced metabolites, and final structure and bioactivity elucidations) has been continuously applied in discovery of new secondary metabolites, it has become a frequent issue that known structures are repeatedly discovered, while a big portion of biosynthetic genes are not expressed under current culturing technologies also termed as "silent" or "cryptic" genes. To increase the silent metabolic potential of the microbial producers, a variety of approaches such as heterologous expression, epigenetic regulation, transcriptional regulation and ribosome engineering, have been developed to affect the biosynthetic process in different gene regulation levels [1-3], among which, transcriptional factor regulation is often adopted because it is feasible and effective, and from which unexpected new secondary metabolites could be obtained by activation of the silent genes.

LaeA is an effective global regulator which was first discovered from Aspergillus nidulans and A. fumigatus by Jin Woo Bok and Nancy P. Keller in 2004 [4], and proved to be able to influence fungi in many aspects, such as increasing [5-7] or reducing secondary metabolite production [8], activating cryptic gene clusters [9], asexual and sexual differentiation as well as changes in phenotype including sporulation [5,9] and pigmentations [5]. Later on, LaeA gene analogues with similar functions were reported from other fungal species such as Penicillium chrysogenum [10], Monascus ruber [11], Alternaria alternate [12], and Dothistroma septosporum [8].

As a part of our ongoing work searching for diverse secondary metabolites from marine derived fungi, we recently isolated one filamentous fungi Penicillium dipodomyis YJ-11 from 
a marine sediment sample collected in Jiaozhou Bay of Qingdao. In order to activate the silent metabolic potential and obtain diversified secondary metabolites, we overexpressed the native global regulator of PdLaeA in P. dipodomyis YJ-11 and the mutant showed changes both in morphologies (sporulation and pigmentations) and metabolic profiles in contrast to the control (Figure 1). Further chemical studies on the mutant strain led to the isolation of two new compounds, 10,11-dihydrobislongiquinolide (1) and 10,11,16,17-tetrahydrobislongiquinolide (2), together with four known analogues, bislongiquinolide (3), also named as bisorbibutenolide, 16,17-dihydrobislongiquinolide (4), also named as dihydrotrichotetronine, sohirnone A (5), and $2^{\prime}, 3^{\prime}$-dihydrosorbicillin (6).

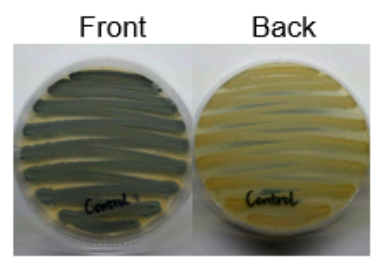

Control

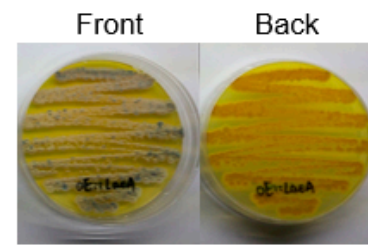

OE::PdLaeA

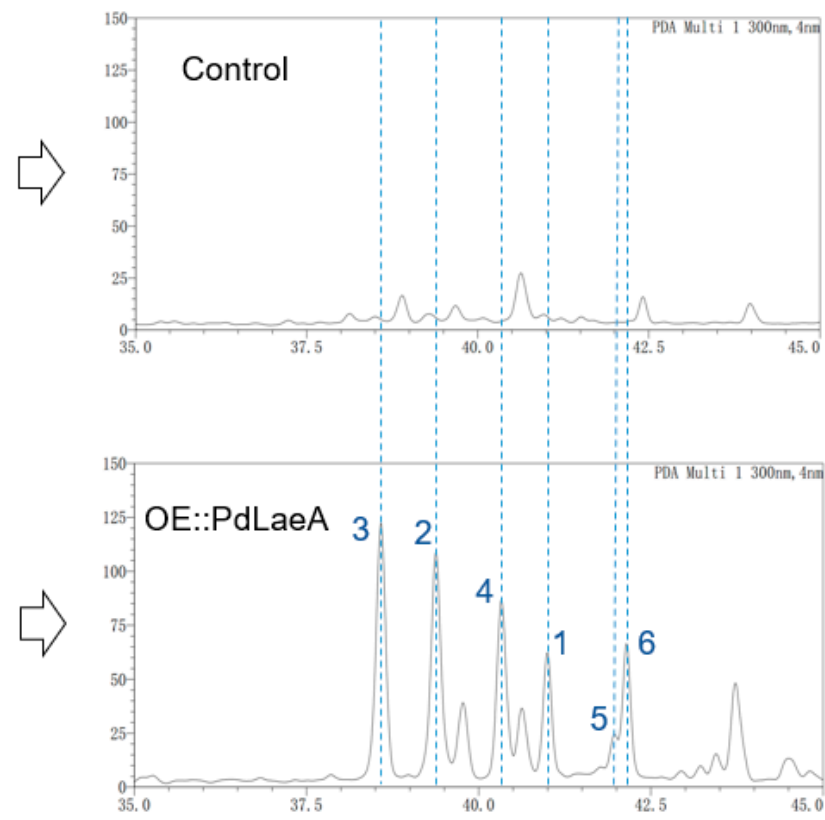

a

b

Figure 1. (a) Morphologies of the control strain and OE::PdLaeA strain of P. dipodomyis YJ- 11 after incubating at $28^{\circ} \mathrm{C}$ for 5 days for sporulation. (b) HPLC analysis of the extracts from the control strain and OE::PdLaeA strain of P. dipodomyis YJ-11.

\section{Results and Discussion}

The LaeA gene analogue PdLaeA was identified via Localblast, using a LaeA gene (Aspergillus nidulans, Q6TLK5.1) as a query. The PdLaeA gene was then cloned from genomic DNA of the strain P. dipodomyis YJ-11. The total size of the gene is $1283 \mathrm{bp}$ and the predicted open reading frame (ORF) is $1053 \mathrm{bp}$, which may encode a polypeptide of 350 amino acids. BLAST analysis by NCBI indicated that the PdLaeA protein had 95\% sequence identity to the protein of PcLaeA (P. citrinum, BAL61197.1), PrLaeA (P. roqueforti FM164, CDM34701.1), PdiLaeA (P. digitatum PHI26, EKV10385.1), and PdiLaeA (P. digitatum Pd1, XP_014530787.1). Phylogenetic analysis revealed that PdLaeA is mostly related to PcLaeA (Figure S2 in Supplementary Materials). Sequence analysis via InterProScan showed that the PdLaeA protein was an S-adenosyl-L-methionine-dependent methyltransferase (IPR029063), which is consistent with the putative mechanism of LaeA genes [13-15].

The PdLaeA in P. dipodomyis YJ-11 was amplified by specific primers (Table S1) and ligated into the vector $\mathrm{pZeo}$ using restriction sites $\mathrm{XhoI}$ and $\mathrm{XbaI}$. The recombinant vector was transformed to $P$. dipodomyis $\mathrm{YJ}-11$ to generate the $\mathrm{OE}:: \mathrm{PdLaeA}$ mutants (the mutant of $P$. dipodomyis $\mathrm{YJ}-11$ harboring vacant $\mathrm{pZeo}$ was also generated as a control). The mutants showed obvious changes on both spore morphology and pigment formation. Followed by fermentation in PDB media with shaking at $28^{\circ} \mathrm{C}$ for 9 days, high performance liquid chromatography (HPLC) analysis also showed a series of new 
peaks presenting in the extract of the OE::PdLaeA mutant compared with that of the control strain (Figure 1), indicating changes in secondary metabolite production.

For exploring the structures for the activation products, the OE::PdLaeA mutant was cultured in larger scale $(10 \mathrm{~L})$. Guided by UPLC-MS data, the EtOAc extract $(12 \mathrm{~g})$ of the fermentation was fractionated by octadecyl silane chemically bonded silica (ODS) medium performance liquid chromatography (MPLC) and then HPLC to yield compounds 10,11-dihydrobislongiquinolide (1, $11 \mathrm{mg})$, 10,11,16,17-tetrahydrobislongiquinolide (2, $35 \mathrm{mg})$, bislongiquinolide which also had been named as bisorbibutenolide [16,17] $(3,18 \mathrm{mg}), 16,17$-dihydrobislongiquinolide (also named as dihydrotrichotetronine $[18,19], 4,84 \mathrm{mg})$, sohirnone A $(5,6 \mathrm{mg})$, and $2^{\prime}, 3^{\prime}$-dihydrosorbicillin $(6,5 \mathrm{mg})$ (Figure 2). The known compounds 3-6 were obtained and identified by the comparation of ${ }^{1} \mathrm{H}$ NMR data and mass spectroscopy with the literature refs. [16-22]. Compounds 3, 5, and $\mathbf{6}$ which had been isolated in our laboratory before [20], were also confirmed by HPLC analysis using standard samples.
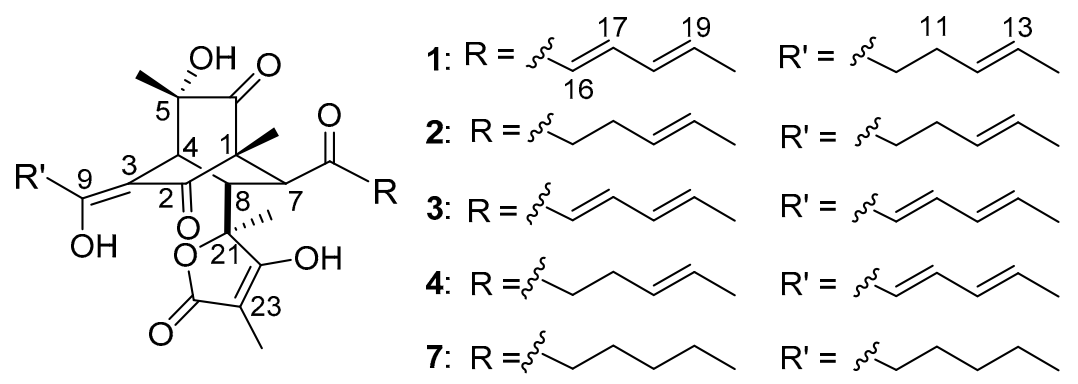<smiles>[R]c1c(O)c(C)cc(C(=O)CC/C=C/C)c1O</smiles>

5: $\mathrm{R}=\mathrm{H}$

6: $\mathrm{R}=\mathrm{CH}_{3}$

Figure 2. Structures of compounds 1-6 isolated from the strain OE::PdLaeA Penicillium dipodomyis YJ-11 and hydrogenation product 7.

Compound 1 was obtained as a yellow powder with the molecular formula $\mathrm{C}_{28} \mathrm{H}_{34} \mathrm{O}_{8}$ supported by the high resolution electrospray ionization mass spectroscopy (HRESIMS) peak at $m / z 497.2185[\mathrm{M}-\mathrm{H}]^{-}$ (calcd. 497.2170). The ${ }^{1} \mathrm{H}$ NMR spectrum of $\mathbf{1}$ revealed six methyl proton signals, two methylene proton signals, nine methine signals including six olefinic ones at $5.0-7.5 \mathrm{ppm}$, and three aliphatic ones at 2.8-3.5 ppm. In the ${ }^{13} \mathrm{C}$ NMR spectrum, in addition to the six methyls, two methylenes and nine methines which were assignable carbon signals, there were 11 quaternary carbons. The unsaturation degree further suggested the presence of three rings in the structure. The ${ }^{1} \mathrm{H}$ and ${ }^{13} \mathrm{C}$ NMR data (Table 1) were very similar to those of bislongiquinolide (3) [16,17] indicating that they had the same core structure. The major differences were the replacement of one double bond (in 3 ) by a single bond (in 1). Careful comparison of the ${ }^{13} \mathrm{C}$ NMR data of $\mathrm{C}_{9}-\mathrm{C}_{14}\left(\delta_{\mathrm{C}} 181.3,32.5,28.4,129.1,126.9\right.$, 17.8 respectively) with those of compound 3 indicated the $\Delta^{10}$ double bond was reduced. The key homonuclear chemical shift correlation spectroscopy (COSY) correlations of $\mathrm{H}-10 / \mathrm{H}-11 / \mathrm{H}-12 / \mathrm{H}-13 / \mathrm{H}-14$ together with ${ }^{1} \mathrm{H}$ detected heteronuclear multiple bond correlation (HMBC) correlations from $\mathrm{H}-11$ $\left(\delta_{\mathrm{H}} 2.42\right)$ to $\mathrm{C}-10\left(\delta_{\mathrm{C}} 32.5\right)$, from $\mathrm{H}-10\left(\delta_{\mathrm{H}} 2.51\right)$ to $\mathrm{C}-12\left(\delta_{\mathrm{C}} 129.1\right), \mathrm{C}-9\left(\delta_{\mathrm{C}} 181.3\right)$, and C-3 $\left(\delta_{\mathrm{C}} 108.4\right)$ (Figure 3) confirmed the structure of $\mathbf{1}$ as the 10,11-hydrogeneted analogue of $\mathbf{3}$, which was named as 10,11-dihydrobislongiquinolide.
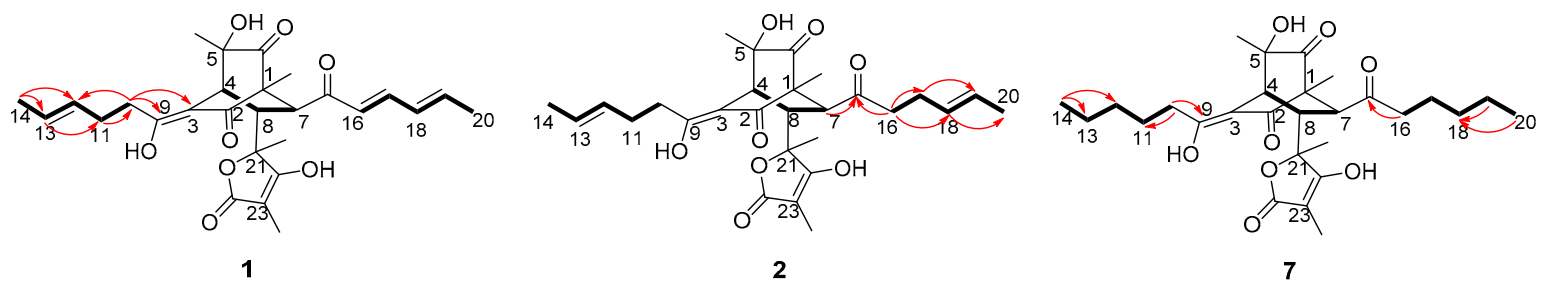

Figure 3. COSY and key HMBC correlations of compounds 1,2 and 7. 
Table 1. ${ }^{1} \mathrm{H}$ NMR data of experimental compounds 1 and $2\left(500 \mathrm{MHz}, \mathrm{CDCl}_{3}, \mathrm{TMS}, \delta \mathrm{ppm}\right)$, literature shared compound $3[16]\left(400 \mathrm{MHz}, \mathrm{CDCl}_{3}, \delta \mathrm{ppm}\right)$, and the hydrogenation product $7\left(600 \mathrm{MHz}, \mathrm{CDCl}_{3}\right.$, TMS, $\delta$ ppm) ( $\mathrm{in} \mathrm{Hz}$.

\begin{tabular}{|c|c|c|c|c|}
\hline No. & 1 & 2 & $3[16]$ & 7 \\
\hline 1 & - & - & - & - \\
\hline 2 & - & - & - & - \\
\hline 3 & - & - & - & - \\
\hline 4 & $3.36 \mathrm{~s}$ & $3.42 \mathrm{~s}$ & 3.36 br. s & $3.39 \mathrm{~s}$ \\
\hline 5 & - & - & - & - \\
\hline 6 & - & - & - & - \\
\hline 7 & $2.95 \mathrm{~d}(7.0)$ & $2.65 \mathrm{~d}(6.6)$ & $3.43 \mathrm{~d}(4.8)$ & $2.75 \mathrm{~d}(7.3)$ \\
\hline 8 & 3.20 br. d (7.0) & 3.15 br. d (6.6) & $3.21 \mathrm{dd}(1.2,4.8)$ & 3.08 br. d (7.3) \\
\hline 9 & - & - & - & - \\
\hline 10 & $2.51 \mathrm{t}(7.4)$ & $2.45-2.60^{\mathrm{a}}$ & $6.12 \mathrm{~d}(15.0)$ & $2.40-2.50^{\mathrm{a}}$ \\
\hline 11 & $2.42 \mathrm{~m}$ & $2.39 \mathrm{~m}$ & $7.33 \mathrm{dd}(15.0,10.6)$ & $1.70 \mathrm{~m}$ \\
\hline 12 & $5.44 \mathrm{dt}(15.3,6.7)$ & $5.44-5.55^{\mathrm{a}}$ & $6.28 \mathrm{dd}(14.4,10.6)$ & $1.30-1.40^{\mathrm{a}}$ \\
\hline 13 & $5.52 \mathrm{dq}(15.3,6.0)$ & $5.44-5.55^{\mathrm{a}}$ & $6.24 \mathrm{dq}(14.4,6.8)$ & $1.30-1.40^{\mathrm{a}}$ \\
\hline 14 & $1.64 \mathrm{~d}(6.0)$ & $1.59-1.67^{\mathrm{a}}$ & $1.88 \mathrm{~d}(6.8)$ & $0.87 \mathrm{t}(7.3)$ \\
\hline 15 & - & - & - & - \\
\hline 16 & $6.02 \mathrm{~d}(15.0)$ & $2.45-2.60^{\mathrm{a}}$ & $6.13 \mathrm{~d}(15.0)$ & $2.40-2.50^{\mathrm{a}}$ \\
\hline 17 & $7.16 \mathrm{dd}(15.0,10.6)$ & $2.11,2.19 \mathrm{~m}$ & $7.22 \mathrm{dd}(15.0,10.4)$ & $1.48 \mathrm{~m}$ \\
\hline 18 & $6.24 \mathrm{dd}(15.0,10.6)$ & $5.34 \mathrm{~m}$ & $6.21 \mathrm{dd}(15.2,10.4)$ & $1.20-1.30^{\mathrm{a}}$ \\
\hline 19 & $6.42 \mathrm{~m}$ & $5.44-5.55^{\mathrm{a}}$ & $6.38 \mathrm{dq}(15.2,7.2)$ & $1.20-1.30^{\mathrm{a}}$ \\
\hline 20 & $1.93 \mathrm{~d}(6.7)$ & $1.59-1.67^{\mathrm{a}}$ & $1.90 \mathrm{~d}(7.2)$ & $0.89 \mathrm{t}(6.5)$ \\
\hline 21 & - & - & - & - \\
\hline 22 & - & - & - & - \\
\hline 23 & - & - & - & - \\
\hline 24 & - & - & - & - \\
\hline $1-\mathrm{CH}_{3}$ & $1.05 \mathrm{~s}$ & $1.13 \mathrm{~s}$ & $1.12 \mathrm{~s}$ & $1.11 \mathrm{~s}$ \\
\hline $5-\mathrm{CH}_{3}$ & $1.34 \mathrm{~s}$ & $1.31 \mathrm{~s}$ & $1.29 \mathrm{~s}$ & $1.30 \mathrm{~s}$ \\
\hline $21-\mathrm{CH}_{3}$ & $1.57 \mathrm{~s}$ & $1.55 \mathrm{~s}$ & $1.51 \mathrm{~s}$ & $1.50 \mathrm{~s}$ \\
\hline $23-\mathrm{CH}_{3}$ & $1.61 \mathrm{~s}$ & $1.71 \mathrm{~s}$ & $1.58 \mathrm{~s}$ & $1.67 \mathrm{~s}$ \\
\hline 9-OH & 14.45 br. s & 14.45 br. s & 13.99 br. s & 14.46 br. s \\
\hline
\end{tabular}

Compound 2 was obtained as a yellow oil and it was analyzed by HRESIMS $\left(m / z 499.2343[\mathrm{M}-\mathrm{H}]^{-}\right.$, calcd. 499.2326) for the molecular formula $\mathrm{C}_{28} \mathrm{H}_{36} \mathrm{O}_{8}$, which was one double bond equivalent (DBE) less than 1 . The ${ }^{1} \mathrm{H}$ NMR spectrum of 2 revealed six methyl proton signals, four methylene proton signals, and seven methine protons with four olefinic ones $\left(\delta_{\mathrm{H}} 5.0-6.0\right)$ and three aliphatic ones $\left(\delta_{\mathrm{H}}\right.$ 2.6-3.5). The ${ }^{1} \mathrm{H}$ and ${ }^{13} \mathrm{C}$ NMR data (Table 1) were very similar to those of $\mathbf{1}$ except that one double bond was hydrogenated in 2. Careful comparison of the ${ }^{13} \mathrm{C}-\mathrm{NMR}$ data of $\mathrm{C}_{15}-\mathrm{C}_{20}$ with those of compound 1 indicated that the $\mathrm{C}_{16}-\mathrm{C}_{17}$ double bond was reduced, which was further confirmed by the COSY correlations $(\mathrm{H}-16 / \mathrm{H}-17 / \mathrm{H}-18, \mathrm{H}-19 / \mathrm{H}-20)$ and $\mathrm{HMBC}$ correlations from $\mathrm{H}-18\left(\delta_{\mathrm{H}} 5.34\right)$ to C-20 $\left(\delta_{\mathrm{C}} 17.8\right)$, from H-17 $\left(\delta_{\mathrm{H}} 2.11\right.$ and $\left.\delta_{\mathrm{H}} 2.19\right)$ to $\mathrm{C}-19\left(\delta_{\mathrm{C}} 126.8\right)$, from H-16 $\left(\delta_{\mathrm{H}} 2.45-2.60\right)$ to $\mathrm{C}-15$ $\left(\delta_{\mathrm{C}} 213.2\right), \mathrm{C}-17\left(\delta_{\mathrm{C}} 25.9\right)$, and C-18 $\left(\delta_{\mathrm{C}} 128.5\right)$ (Figure 3). Thus, the structure of 2 was established and named as 10,11,16,17-tetrahydrobislongiquinolide.

The relative and absolute configurations of compounds $\mathbf{1}$ and $\mathbf{2}$ were determined by nuclear overhauser effect spectroscopy (NOESY) correlations (Figure 4), coupling constants (Table 1), hydrogenation reaction (Figure 5), circular dichroism (CD) spectra (Figure 6), and biogenetic considerations. In compound $\mathbf{1}$, the $E$ geometries of the double bonds in the side chains were deduced by the large coupling constants $(15.0 \mathrm{~Hz})$. In compound 2, the NOESY correlation (Figure 4) between 1- $\mathrm{CH}_{3}\left(\delta_{\mathrm{H}} 1.13\right)$ and $\mathrm{H}-16\left(\delta_{\mathrm{H}} 2.45-2.60\right)$ suggested the same orientation of $1-\mathrm{CH}_{3}$ and the chain from C-7 through C-20; the NOESY correlation between $\mathrm{H}-4\left(\delta_{\mathrm{H}} 3.42\right)$ and $\mathrm{H}-10\left(\delta_{\mathrm{H}} 2.45-2.60\right)$ indicated a $Z$ geometry of $\Delta^{3,9}$ and located H-4 to the same side of the chain from C-9 through 
C-14, which was supported by the similar chemical shifts as reported for the known structure of bislongiquinolide [17] and bisorbibutenolide [16]. The NOESY correlation of $5-\mathrm{CH}_{3}\left(\delta_{\mathrm{H}} 1.31\right) / \mathrm{H}-10$ suggested that $5-\mathrm{CH}_{3}$ faced to $\mathrm{C}-3$ in the bicyclo[2.2.2] ring. The $7 R^{*}, 8 S^{*}$ relative configuration was suggested by the coupling constant $\left({ }^{3} \mathrm{~J}_{\mathrm{H}-7, \mathrm{H}-8}=6.6 \mathrm{~Hz}\right)$ [16]. The NOESY correlation of $\mathrm{H}-16 / 23-\mathrm{CH}_{3}$ $\left(\delta_{\mathrm{H}} 1.71\right)$ indicated that the $23-\mathrm{CH}_{3}$ pointed to the direction of the side chain from $\mathrm{C}-15$ to $\mathrm{C}-20$, while the NOESY correlations of $\mathrm{H}-10 / 21-\mathrm{CH}_{3}$ and $\mathrm{H}-4 / 21-\mathrm{CH}_{3}$ oriented $21-\mathrm{CH}_{3}$ to another side chain from $\mathrm{C}-9$ to $\mathrm{C}-14$ and $\mathrm{H}-4$. Thus, the relative configuration of compound 2 should be $1 R^{*}, 4 S^{*}, 5 S^{*}, 7 R^{*}$, $8 S^{*}, 21 S^{*}$, which adopted the same configuration of the bicyclo[2.2.2] octanedione core as the reported analogues $[16,17]$.

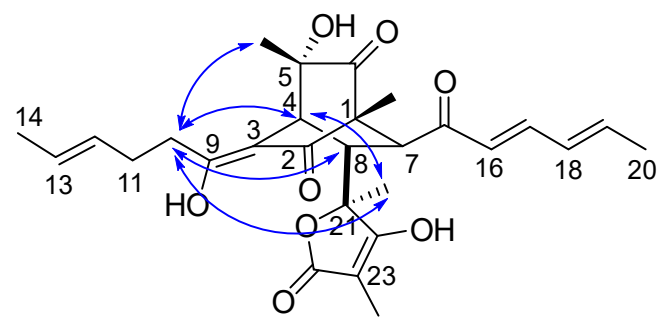

1

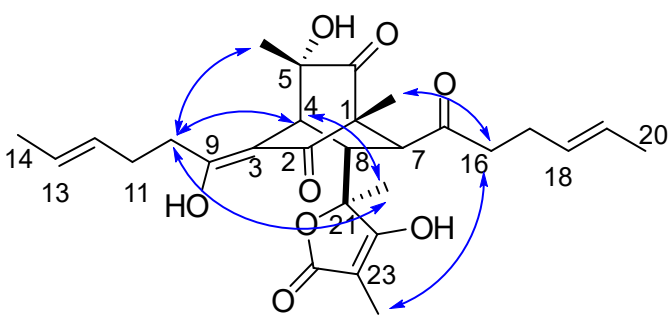

2

Figure 4. Key NOESY correlations of compounds 1 and 2.

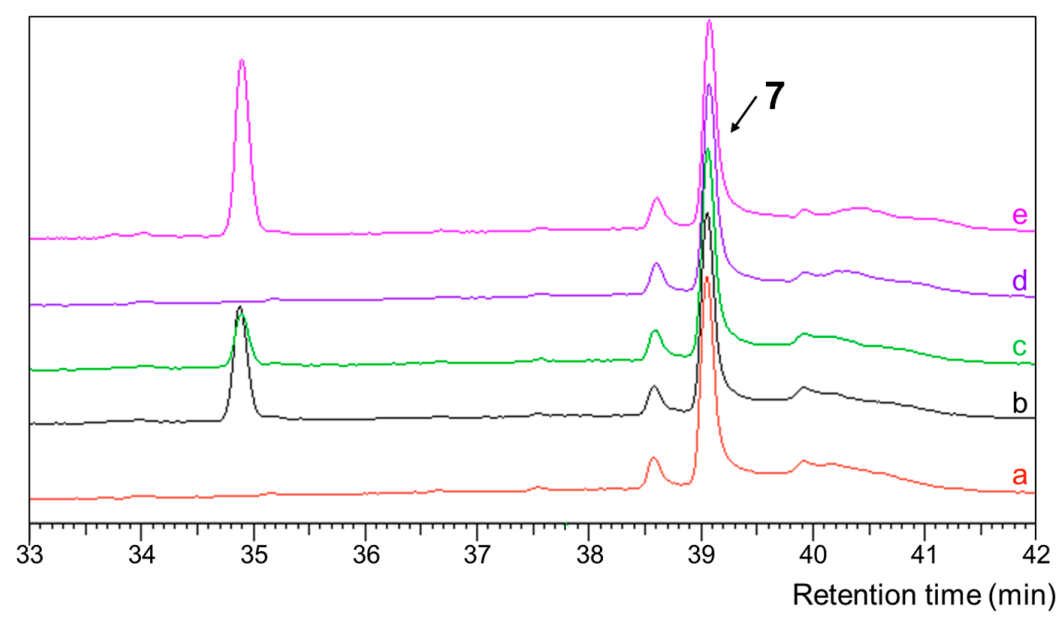

Figure 5. HPLC analysis of hydrogenation reaction products: (a-d) represent the reaction products of compounds 1-4 respectively and (e) is a co-injection of all the reaction products of compounds 1-4.

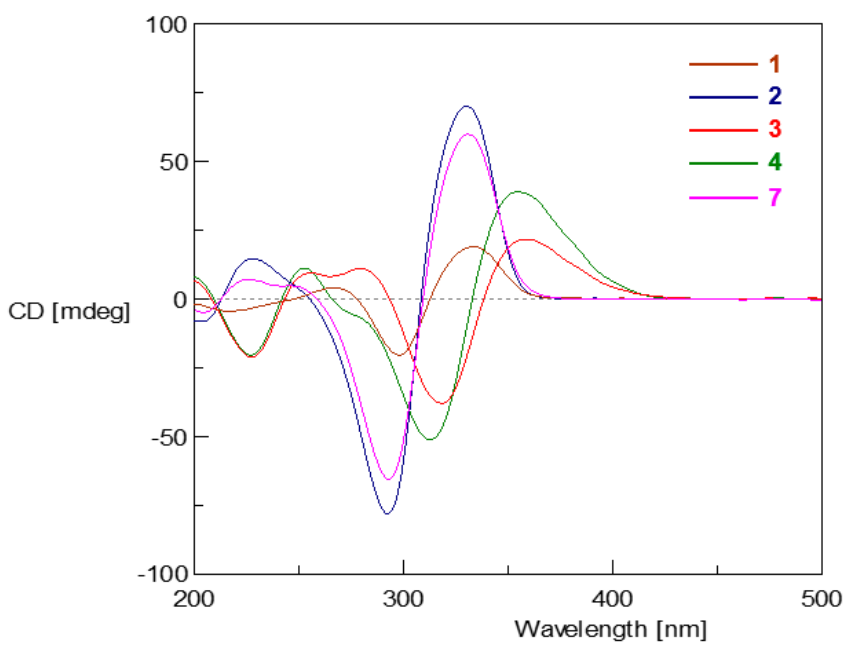

Figure 6. Circular dichroism (CD) spectra of 1-4 and 7. 
To confirm the consistent configurations of the co-isolated compounds 1-4, hydrogenation over palladium on carbon was performed respectively. HPLC analysis of the reaction products showed that compounds 1-4 gave the same hydrogenation product (Figure 5), which suggested identical configurations of compounds 1-4 core structures. The hydrogenated product, named octahydrobislongiquinolide (7), was isolated by HPLC.

Compound 7 was obtained as a white powder with the molecular formula $\mathrm{C}_{28} \mathrm{H}_{40} \mathrm{O}_{8}$ supported by the HRESIMS peak at $m / z 527.2608[\mathrm{M}+\mathrm{Na}]^{+}$(calcd. 527.2615). In addition to the signals expected for the bicyclo[2.2.2] core structure and the butyrolactone ring, the 1D NMR spectra of $\mathbf{7}$ shows signals for two methyls, eight methylenes, and no olefinic proton indicating that the double bonds in the sorbyl side chains were hydrogenated thoroughly. The key COSY correlations of $\mathrm{H}-10 / \mathrm{H}-11 / \mathrm{H}-12 / \mathrm{H}-13 / \mathrm{H}-14$ together with $\mathrm{HMBC}$ correlations from $\mathrm{H}-14\left(\delta_{\mathrm{H}} 0.87\right)$ to $\mathrm{C}-13\left(\delta_{\mathrm{C}} 31.9\right)$ and $\mathrm{C}-12\left(\delta_{\mathrm{C}} 22.5\right)$, from $\mathrm{H}-10$ $\left(\delta_{\mathrm{H}} 2.40-2.50\right)$ to $\mathrm{C}-11\left(\delta_{\mathrm{C}} 25.2\right)$ and $\mathrm{C}-9\left(\delta_{\mathrm{C}} 182.4\right)$ (Figure 3$)$ confirmed the structure of one sidechain. Similarly, the key COSY correlations of $\mathrm{H}-16 / \mathrm{H}-17 / \mathrm{H}-18 / \mathrm{H}-19 / \mathrm{H}-20$ together with HMBC correlations from $\mathrm{H}-16\left(\delta_{\mathrm{H}} 2.40-2.50\right)$ to $\mathrm{C}-15\left(\delta_{\mathrm{C}} 214.3\right)$, from $\mathrm{H}-19\left(\delta_{\mathrm{H}} 1.20-1.30\right)$ to $\mathrm{C}-18\left(\delta_{\mathrm{C}} 31.0\right)$, from $\mathrm{H}-20$ $\left(\delta_{\mathrm{H}} 0.89\right)$ to $\mathrm{C}-18\left(\delta_{\mathrm{C}} 31.0\right)$ (Figure 3$)$ confirm the structure of the other sidechain. Thus, the structure of 7 was established and named as octahydrobislongiquinolide.

Therefore, the absolute configurations of $\mathbf{1}$ and $\mathbf{2}$ were proposed to be the same as the co-isolated 3 and $\mathbf{4}$, which were also supported by the optical rotation values $(\mathbf{1}, \mathbf{2}, \mathbf{3}, \mathbf{4}:+35.6,+71.8,+105$ [17], +350 [19]), the biogenetic consideration, and the similar trend in CD curves (Figure 6). Moreover, in the CD spectrum as shown in Figure 6, the curves of compounds 1-4 and 7 clustered into two groups (1, 2, and 7 were in one group and 3 and 4 belonged to the other), which suggested that the double bond at $\mathrm{C}-10$ on the 3-sorbyl substitution made a dominant contribution to the shape of the CD spectrum compared with the double bonds at other positions such as C-12, C-16 and C-18 in bicyclo[2.2.2]octanedione containing sorbicillinoid structures.

The cytotoxicities of compounds 1-4 were evaluated using HL-60, K562, BEL-7402, HCT-116, A549, Hela, L-02, MGC-803, SH-SY5Y, PC-3, H446, U87, MDA-MB-231, HO8910, ASPC-1 and MCF- 7 cell lines, but none of them presented a cytotoxic effect at $30 \mu \mathrm{M}$. The antimicrobial activity was also evaluated, with no activity detected under the concentration of $30 \mu \mathrm{M}$ either. Compounds 1-4 exhibited identical weak siderophore activity with chrome azurol sulfonate (CAS) with an $\mathrm{ED}_{50}$ value of $400 \mu \mathrm{M}$ (deferoxamine mesylate was used as a positive control with an $\mathrm{ED}_{50}$ value of $100 \mu \mathrm{M}$ ). Inspired by the radical scavenging activity of the known compound 3 [16], 1,1-diphenyl-2-picrylhydrazyl radical 2,2-diphenyl-1-(2,4,6-trinitrophenyl)hydrazyl (DPPH) radical scavenging assay was used to test the radical scavenging activity of compounds $\mathbf{2}-\mathbf{4}$ (a paucity of compound $\mathbf{1}$ prevented analysis), and they showed similar effects with $\mathrm{ED}_{50}$ values of $166.7 \mu \mathrm{M}, 183.3 \mu \mathrm{M}$, and $89.6 \mu \mathrm{M}$ (the value of ascorbic acid was $27.3 \mu \mathrm{M}$ as positive control).

The sorbicillinoids are a family of hexaketide metabolites, with the presence of the sorbyl sidechain as a unique structural feature. Monomeric, dimeric, trimeric, and nitrogen-containing metabolites constitute the sorbicillinoids, among which dimers are the most common, with potential bioactivities as drug leads $[23,24]$. The compounds $\mathbf{1 - 4}$ in this report are an expansion of the library of the bridged bicyclic bisorbicillinoids with the bicyclo[2.2.2]octanedione core structure. In contrast to the previous discovery strategies of conventional extraction and separation, biosynthesis or total synthesis, it is the first report of sorbicillinoid discovery by activating silent gene clusters. The above result shows that overexpression of the global regulator LaeA is a useful method to discover new natural products by activating silent biosynthetic gene clusters.

\section{Materials and Methods}

\subsection{General Experimental Procedures}

DNA restriction enzymes were used as recommended by the manufacturer (New England Biolabs, NEB, Beijing, China). Polymerase chain reaction (PCR) was performed using TransStart ${ }^{\circledR}$ Fastpfu DNA 
Polymerase (Transgen Biotech, Beijing, China). PCR products were confirmed by PCR analysis using $2 \times$ EasyTaq $^{\circledR}$ PCR SuperMix (Transgen Biotech, Beijing, China). Genomic DNA samples were prepared using the CTAB isolation buffer at $\mathrm{pH} 8.0(20 \mathrm{~g} / \mathrm{L}$ cetyltrimethylammonium bromide, $1.4 \mathrm{M}$ sodium chloride, and $20 \mathrm{mM}$ EDTA) [25]. The gene-specific primers are listed in Table S1. UV spectra were recorded on a Beckman DU 640 spectrophotometer (Beckman Coulter Inc., Brea, CA, USA). Specific optical rotations were obtained using a JASCO P-1020 digital polarimeter (JASCO Corporation, Tokyo, Japan). Electrospray ionization-mass spectrometry (ESIMS) and HRESIMS were obtained on a Thermo Scientific LTQ Orbitrap XL mass spectrometer (Thermo Fisher Scientific, Waltham, MA, USA) or using a Micromass Q-TOF ULTIMA GLOBAL GAA076 LC Mass spectrometer (Wasters Corporation, Milford, MA, USA). ${ }^{1} \mathrm{H}$ NMR, ${ }^{13} \mathrm{C}$ NMR and 2D NMR spectra were recorded on an Agilent $500 \mathrm{MHz}$ DD2 spectrometer (Agilent Technologies Inc., Santa Clara, CA, USA). LC-MS was performed using an Acquity UPLC H-Class coupled to a SQ Detector 2 mass spectrometer using a BEH C18 column $(1.7 \mu \mathrm{m}, 2.1 \times 50 \mathrm{~mm}, 1 \mathrm{~mL} / \mathrm{min}$ ) (Waters Corporation, Milford, MA, USA). Semi-preparative HPLC (YMC Co., Ltd., Kyoto, Japan) was performed on an ODS column (YMC-Pack ODS-A, $10 \times 250 \mathrm{~mm}$, $5 \mu \mathrm{m}, 3 \mathrm{~mL} / \mathrm{min}$ ). Medium-pressure liquid chromatography (MPLC) was performed on a Bona-Agela CHEETAHTM HP100 (Beijing Agela Technologies Co., Ltd., Beijing, China) [26].

\subsection{Materials and Culture Conditions}

The fungal strain, authenticated as P. dipodomyis YJ-11, was collected from the marine sediment around the sewage outlet in Jiaozhou Bay of Qingdao. The strain was identified by internal transcribed spacer (ITS) sequence and the sequence data were submitted to GenBank (accession number: MK682303). Working stocks were prepared on Potato Dextrose agar slants stored at $4{ }^{\circ} \mathrm{C}$ in our laboratory.

The strain was incubated in media potato dextrose agar (PDA, 20\% potato, $2 \%$ dextrose, and $2 \%$ agar) at $28{ }^{\circ} \mathrm{C}$ for 5 days for sporulation. Media potato sorbitol agar (PSA, $20 \%$ potato, $2 \%$ dextrose, 1.2 M D-sorbitol, and $\%$ agar) and PDA with $400 \mu \mathrm{g} / \mathrm{mL}$ zeocin (Sigma) were used to screen resistant transformants. The mutants were also cultured at $28^{\circ} \mathrm{C}$ in an incubator. For compound production, the strains were cultured on potato dextrose (PDB, $20 \%$ potato and $2 \%$ dextrose) at $28{ }^{\circ} \mathrm{C}, 180 \mathrm{rpm}$ for 9 days. Trans1-T1 Phage Resistant Chemically competent cell (Transgen Biotech, Beijing, China) was used for plasmid preservation and amplification, following standard recombinant DNA techniques. E. coli cultures were growing at $37^{\circ} \mathrm{C}$ in another incubator.

\subsection{Sequence Analysis of the PdLaeA Gene}

The LaeA gene was analyzed by Localblast with the reported LaeA obtained in national center for biotechnology information (NCBI). For the multiple sequence alignment analysis, the amino acid sequences of PdLaeA and other LaeA homologues from different species retrieved from NCBI were aligned using the ClustalX software [27]. The phylogenetic analysis was conducted with the MEGA7 software [28]. The conserved domain of the PdLaeA protein was scanned by the InterProScan program [29].

\subsection{Construction of the PdLaeA Expression Vector}

The overexpression vector pZeo which mainly contains a constitutive promoter PgpdA, resistant ampicillin gene and resistant zeocin gene as selection markers was digested with restriction endonucleases XhoI and XbaI. The PdLaeA gene was PCR-amplified (from genomic DNA of the wild-type strain $P$. dipodomyis $\mathrm{YJ}-11$ ) using specific primers containing $\mathrm{XhoI}$ and $\mathrm{XbaI}$ restriction sites (Table S1). The PCR products were digested with the same endonucleases and PdLaeA gene was introduced into pZeo vector to generate pZeo-PdLaeA (Figure S3 in Supplementary Materials). The recombinant vector was transformed into competent E. coli strain Trans1-T1 to extract plasmids for transformation. 


\subsection{Fungal Protoplast Formation and Transformation}

The strain P. dipodomyis YJ-11 was first grown on PDA plates at $28{ }^{\circ} \mathrm{C}$ for 5 days. Fresh spores were collected into $50 \mathrm{~mL}$ PDB together with yeast extract media in $250 \mathrm{~mL}$ Erlenmeyer flasks and germinated at $28^{\circ} \mathrm{C}$ and $180 \mathrm{rpm}$ for about $7 \mathrm{~h}$. Mycelia were gathered by centrifugation at $4000 \mathrm{rpm}$ for $15 \mathrm{~min}$, and washed by $25 \mathrm{~mL}$ osmotic buffer (1.2 $\mathrm{M} \mathrm{MgSO}_{4}, 10 \mathrm{mM}$ sodium phosphate, $\left.\mathrm{pH} 5.8\right)$. Subsequently, the mycelia were suspended into $10 \mathrm{~mL}$ of osmotic buffer containing $30 \mathrm{mg}$ lysing enzymes from Trichodema harzianum (Sigma) and $20 \mathrm{mg}$ Yatalase (TaKaRa), transferred into an empty sterile bottle, and cultured in a shaker of $28^{\circ} \mathrm{C}$ at $80 \mathrm{rpm}$ overnight to form protoplast.

After the whole night, the mixture was collected in a $50 \mathrm{~mL}$ centrifuge tube and covered gently with isopyknic protoplast trapping buffer $(0.6 \mathrm{M}$ sorbitol, $0.1 \mathrm{M} \mathrm{pH}$ 7.0 Tris- $\mathrm{HCl})$. After centrifugation at $4000 \mathrm{rpm}$ for $15 \mathrm{~min}$ at $4{ }^{\circ} \mathrm{C}$, protoplasts were collected in the interface of the above two buffers. The protoplasts were then transferred to a sterile $50 \mathrm{~mL}$ centrifuge tube and washed by $20 \mathrm{~mL}$ STC buffer (1.2 M sorbitol, $10 \mathrm{mM} \mathrm{CaCl} 2,10 \mathrm{mM} \mathrm{pH} \mathrm{7.5} \mathrm{Tris-HCl).} \mathrm{The} \mathrm{protoplasts} \mathrm{were} \mathrm{resuspended} \mathrm{in}$ $2 \mathrm{~mL} \mathrm{STC}$ buffer for transformation. Then, the freeze-drying plasmids pZeo-PdLaeA and the plasmid pZeo (the desired mutants were regarded as a control in the following crude analysis) were dissolved in $50 \mu \mathrm{L}$ STC buffer, followed by $100 \mu \mathrm{L}$ protoplast suspension and the mixture incubated for $60 \mathrm{~min}$ on ice. Next, $600 \mu \mathrm{L}$ of polyethylene glycol (PEG) solution (60\% PEG, $50 \mathrm{mM}$ calcium chloride and $50 \mathrm{mM} \mathrm{pH} 7.5$ Tris- $\mathrm{HCl}$ ) was added to the protoplast mixture, and the mixture was incubated at room temperature for an additional $25 \mathrm{~min}$. The mixture was spread on the regeneration solid PSA medium (PDA medium with $1.2 \mathrm{M}$ sorbitol and $400 \mu \mathrm{g} / \mathrm{mL}$ zeocin) and incubated at $28^{\circ} \mathrm{C}$ for around 4 days [30].

\subsection{Transformants Screening}

After regeneration, the transformants were passaged to PDA plates with $400 \mu \mathrm{g} / \mathrm{mL}$ zeocin respectively. Zeocin resistant mutants were transferred onto new PDA media containing $400 \mu \mathrm{g} / \mathrm{mL}$ zeocin for the second screening. The strains that were able to grow were subjected to further PCR analysis validation. The putative OE::PdLaeA mutants and the wild-type strain were cultured on PDA media for 5 days at $28^{\circ} \mathrm{C}$ in an incubator in order to extract genomic DNAs. PCR analysis to confirm the gene insertion was carried out using three pairs of primers to verify the zeocin resistant mutants as shown in Table S1 and Figure S4 (primers gpda-1 and gpda-2 to verify whole of the PdLaeA gene, primers gpda- 1 and YZ-LaeA-F to verify the upstream of target gene, primers gpda-2 and YZ-LaeA-R to verify the downstream of target gene). Those transformants which went through all these verifications were recognized as the desired mutants.

\subsection{Fermentation and Extraction}

For small-scale analysis, the OE::PdLaeA mutant strains and the control strain were grown on PDA plates for 5 days at $28^{\circ} \mathrm{C}$. Shortly after sporing, they were inoculated into $150 \mathrm{~mL}$ of PDB medium and cultured at $28^{\circ} \mathrm{C}, 180 \mathrm{rpm}$. Nine days later, the cultures were extracted with twice the volume of ethyl acetate. The organic phase was evaporated and the residue was dissolved in $\mathrm{MeOH}$, which was analyzed by HPLC and indicated that one of the six mutants showed an apparent change in metabolite production (Figure 1).

For compound isolation, the selected strain was initially handled the same as above. Then a large-scale fermentation was performed in $500 \mathrm{~mL}$ Erlenmeyer flasks (total $10 \mathrm{~L}$ ) for further incubation. The broth was extracted three times with ethyl acetate to give a total of $60 \mathrm{~L}$ of extract solution. The organic phase was evaporated under reduced pressure to afford a crude residue ( $12 \mathrm{~g})$.

\subsection{Compound Isolation}

The crude extracts were separated by MPLC ( $60 \%$ to $100 \% \mathrm{MeOH}$ in $\mathrm{H}_{2} \mathrm{O}$ for $\left.60 \mathrm{~min}\right)$. The fractions containing the target compounds were combined and concentrated to give 7 fractions (Fr.1 to Fr.7). For further purification, semi-preparative HPLC were carried out. Fr.4 was then purified by HPLC 
(55\% MeCN in $\left.\mathrm{H}_{2} \mathrm{O}, 0.5 \% \mathrm{THF}\right)$ to obtain Fr.4-1 (6; $\left.5 \mathrm{mg} ; \mathrm{t}_{\mathrm{R}} 24.2 \mathrm{~min}\right)$. Fr.5 was purified by HPLC (42\% MeCN in $\mathrm{H}_{2} \mathrm{O}, 0.5 \%$ THF) to obtain Fr.5-1 (3;18 mg; $\left.\mathrm{t}_{\mathrm{R}} 30.8 \mathrm{~min}\right)$ and Fr.5-2 (1; $\left.7 \mathrm{mg} ; \mathrm{t}_{\mathrm{R}} 38.0 \mathrm{~min}\right)$. Fr.6 was purified by HPLC ( $60 \% \mathrm{MeOH}$ in $\mathrm{H}_{2} \mathrm{O}, 0.5 \%$ THF) to give five subfractions (Fr.6- 1 to Fr.6-5), in which Fr.6-1 (1; 4 mg; $\left.t_{R} 30.3 \mathrm{~min}\right)$, Fr.6-4 (2; $\left.35 \mathrm{mg} ; \mathrm{t}_{\mathrm{R}} 46.1 \mathrm{~min}\right)$, Fr.6-5 (5; $\left.6 \mathrm{mg} ; \mathrm{t}_{\mathrm{R}} 52.2 \mathrm{~min}\right)$ were proven to be pure. Fr.6-3-1 $\left(4 ; 84 \mathrm{mg}\right.$; $\left.\mathrm{t}_{\mathrm{R}} 20.5 \mathrm{~min}\right)$ was purified by $\mathrm{HPLC}\left(50 \% \mathrm{MeCN}\right.$ in $\mathrm{H}_{2} \mathrm{O}, 0.5 \%$ THF) from Fr.6-3. The purity of each compound was checked by LC-MS and the structures were confirmed by NMR including ${ }^{1} \mathrm{H},{ }^{13} \mathrm{C}$, and 2D NMR spectra.

10,11-Dihydrobislongiquinolide (1): $[\alpha]_{\mathrm{D}}^{20} 35.6$ (c 0.13, MeOH), UV (MeOH) $\lambda_{\max }(\log \varepsilon): 228$ (3.67), $296(2.97) \mathrm{nm},{ }^{1} \mathrm{H}-\mathrm{NMR}\left(\mathrm{CDCl}_{3}, 500 \mathrm{MHz}\right)$ and ${ }^{13} \mathrm{C}-\mathrm{NMR}\left(\mathrm{CDCl}_{3}, 125 \mathrm{MHz}\right)$ data are shown in Tables 1 and 2, HRESIMS m/z: $497.2185[\mathrm{M}-\mathrm{H}]^{-}$(Calcd. for $\mathrm{C}_{28} \mathrm{H}_{34} \mathrm{O}_{8}: 497.2170$ ).

10,11,16,17-Tetrahydrobislongiquinolide (2): $[\alpha]_{\mathrm{D}}^{20} 71.8$ (c 0.50, MeOH), UV (MeOH) $\lambda_{\max }(\log \varepsilon)$ : 237 (1.22), 296 (3.24) nm, ${ }^{1} \mathrm{H}-\mathrm{NMR}\left(\mathrm{CDCl}_{3}, 500 \mathrm{MHz}\right)$ and ${ }^{13} \mathrm{C}-\mathrm{NMR}\left(\mathrm{CDCl}_{3}, 125 \mathrm{MHz}\right)$ data are shown in Tables 1 and 2, HRESIMS m/z: $499.2343[\mathrm{M}-\mathrm{H}]^{-}$(Calcd. for $\mathrm{C}_{28} \mathrm{H}_{36} \mathrm{O}_{8}: 499.2326$ ).

Table 2. ${ }^{13} \mathrm{C}$ NMR data of experimental compounds 1 and $2\left(125 \mathrm{MHz}, \mathrm{CDCl}_{3}, \mathrm{TMS}, \delta \mathrm{ppm}\right)$, literature shared compound $3[16]\left(100 \mathrm{MHz}, \mathrm{CDCl}_{3}, \delta \mathrm{ppm}\right)$ and the hydrogenation product $7\left(150 \mathrm{MHz}, \mathrm{CDCl}_{3}\right.$, TMS, $\delta$ ppm).

\begin{tabular}{|c|c|c|c|c|}
\hline No. & 1 & 2 & 3 [16] & 7 \\
\hline 1 & 61.7 & 61.4 & 62.6 & 61.4 \\
\hline 2 & 193.0 & 192.9 & 194.9 & 192.9 \\
\hline 3 & 108.4 & 108.4 & 108.5 & 106.3 \\
\hline 4 & 42.8 & 42.7 & 42.4 & 42.9 \\
\hline 5 & 75.3 & 75.2 & 75.0 & 75.3 \\
\hline 6 & 209.9 & 209.1 & 208.3 & $209.2^{b}$ \\
\hline 7 & 50.7 & 54.0 & 51.3 & 54.3 \\
\hline 8 & 42.0 & 42.6 & 43.6 & 42.7 \\
\hline 9 & 181.3 & 181.2 & 169.8 & 182.4 \\
\hline 10 & 32.5 & 32.4 & 117.6 & 32.4 \\
\hline 11 & 28.4 & 28.4 & 143.9 & 25.2 \\
\hline 12 & 129.1 & 129.0 & 130.3 & 22.5 \\
\hline 13 & 126.9 & 126.9 & 140.9 & 31.9 \\
\hline 14 & 17.8 & 17.8 & 18.9 & 14.0 \\
\hline 15 & 202.1 & 213.2 & 202.7 & 214.3 \\
\hline 16 & 127.2 & 45.9 & 127.0 & 46.0 \\
\hline 17 & 148.3 & 25.9 & 148.0 & 22.5 \\
\hline 18 & 130.1 & 128.5 & 131.0 & 31.0 \\
\hline 19 & 146.0 & 126.8 & 145.5 & 29.8 \\
\hline 20 & 19.2 & 17.8 & 19.1 & 14.0 \\
\hline 21 & 83.1 & 84.0 & 83.2 & 83.1 \\
\hline 22 & 175.8 & 177.3 & 176.5 & 176.0 \\
\hline 23 & 98.8 & 97.8 & 98.2 & 98.2 \\
\hline 24 & 174.4 & 175.4 & 174.9 & 173.6 \\
\hline $1-\mathrm{CH}_{3}$ & 10.5 & 10.6 & 11.0 & 10.7 \\
\hline $5-\mathrm{CH}_{3}$ & 24.1 & 24.0 & 23.5 & 24.2 \\
\hline $21-\mathrm{CH}_{3}$ & 21.8 & 21.3 & 23.1 & 21.5 \\
\hline $23-\mathrm{CH}_{3}$ & 6.1 & 5.9 & 6.3 & 6.1 \\
\hline
\end{tabular}

${ }^{\mathrm{b}}$ Detected by HMBC spectrum.

\subsection{Hydrogenation of Compounds 1-4}

Compounds 1-4 in methanol were hydrogenated over palladium on carbon at room temperature overnight, respectively. The reaction mixture was filtered, concentrated, and purified by semipreparative $\mathrm{HPLC}\left(65 \% \mathrm{MeOH}\right.$ in $\mathrm{H}_{2} \mathrm{O}, 0.1 \%$ THF) to give octahydrobislongiquinolide $(7 ; 5 \mathrm{mg}$; 
$\left.t_{R} 15.6 \mathrm{~min}\right)$. The purity of compound 7 was checked by LC-MS and the structures were confirmed by NMR including ${ }^{1} \mathrm{H},{ }^{13} \mathrm{C}$ and 2D NMR spectra.

Octahydrobislongiquinolide (7): $[\alpha]_{\mathrm{D}}^{20} 78.4$ (c 0.10, MeOH), UV (MeOH) $\lambda_{\max }(\log \varepsilon): 227$ (4.78), $297(2.13) \mathrm{nm},{ }^{1} \mathrm{H}-\mathrm{NMR}\left(\mathrm{CDCl}_{3}, 600 \mathrm{MHz}\right)$ and ${ }^{13} \mathrm{C}-\mathrm{NMR}\left(\mathrm{CDCl}_{3}, 150 \mathrm{MHz}\right)$ data are shown in Tables 1 and 2, HRESIMS $m / z$ : $527.2608[\mathrm{M}+\mathrm{Na}]^{+}$(calcd. 527.2615 for $\mathrm{C}_{28} \mathrm{H}_{40} \mathrm{O}_{8} \mathrm{Na}$ ).

\subsection{Assay of Cytotoxicity, Antimicrobial and Antioxidation Activity}

These biological evaluations were carried out as previously reported in References [26,31].

\subsection{Assay of Siderophore Activity}

Siderophore activity was evaluated by the chrome azurol sulfonate (CAS) assay. Buffer A consist of $50 \mathrm{~mL} 5 \mathrm{M}$ CAS solution and $10 \mathrm{~mL} \mathrm{Fe}^{3+}$ solution $\left(1 \mathrm{mM} \mathrm{FeCl} \mathrm{F}_{3} \cdot 6 \mathrm{H}_{2} \mathrm{O}, 10 \mathrm{mM} \mathrm{HCl}\right) .72 .9 \mathrm{mg}$ hexadecyl trimethyl ammonium bromide (HDTMA) was dissolved in $40 \mathrm{~mL}$ water after heated as buffer B. Buffer B was then slowly added to buffer A under stirring to afford $100 \mathrm{~mL}$ CAS assay solution. All tested compounds were dissolved in $\mathrm{MeOH}$ at stepwise concentrations (1-100 mM) then $99 \mu \mathrm{L}$ of the compound solution and $1 \mu \mathrm{L}$ CAS assay solution were dispensed into wells of a 96-well microtiter tray. The mixture was shaken and left to stand for $4 \mathrm{~h}$. After that, absorbance was measured at $630 \mathrm{~nm}$ and the inhibition rate was calculated. Deferoxamine mesylate, which could make the color change of CAS from blue to orange, was used to determine standard curves relating the CAS reactivity to iron-binding ligands. The $\mathrm{ED}_{50}$ values denoted the concentration of sample required to remove $50 \%$ of the iron in CAS solution [32,33].

\section{Conclusions}

In summary, guided by bioinformatic analysis of the genomic sequence of P. dipodomyis YJ-11, we discovered one global regulator of PdLaeA. Further overexpression of the PdLaeA gene in P. dipodomyis $\mathrm{YJ}-11$ led to the discovery of two new compounds, 10,11-dihydrobislongiquinolide (1), 10,11,16,17-tetrahydrobislongiquinolide (2), together with four known sorbicillin analogues (compounds 3-6). This is the first report on application of global regulator LaeA in P. dipodomyis with the purpose of increasing the secondary metabolite producing potential. This result also indicated that the production of sorbicillinoids may be regulated by the global regulator LaeA.

Supplementary Materials: The following are available online at http://www.mdpi.com/1660-3397/17/8/446/s1, Figure S1: AntiSMASH analysis of the genome of the strain Penicillium dipodomyis YJ-11, Figure S2: Phylogenetic tree analysis of PdLaeA and its homologs from different species, Figure S3: Map of the vector pZeo and PdLaeA overexpression plasmid pZeo-PdLaeA, Figure S4: PCR analysis for confirming the gene insertion, Figures S5-S11: 1D, 2D NMR and HRESIMS spectra of 10,11-dihydrobislongiquinolide (1), Figures S12-S18: 1D, 2D NMR and HRESIMS spectra of 10,11,16,17-tetrahydrobislongiquinolide (2). Figures S19-S20: 1D NMR spectra of bislongiquinolide (3). Figures S21-S22: 1D NMR spectra of 16,17-dihydrobislongiquinolide (4), Figures S23-S28: 1D, 2D NMR and HRESIMS spectra of octahydrobislongiquinolide (7), Table S1: The primers used in this study.

Author Contributions: The contributions of the respective authors are as follows: J.Y. drafted the work, constructed the plasmids and performed the fermentation, extraction, as well as the isolation. X.Z., H.H., and C.M. were involved in the acquisition of mutant strains and bioinformatic analysis. J.Y. and C.S. elucidated the constituents and performed the biological evaluations. Q.C., Q.G., T.Z., and G.Z. contributed to checking and confirming all procedures of isolation and identification. D.L. designed the study, supervised the laboratory work, and contributed to the critical reading of the manuscript, and was also involved in structural determination and bioactivity elucidation. All the authors have read the final manuscript and approved the submission.

Funding: This work was financially supported by the Fundamental Research Funds for the Central Universities (201941001), NSFC-Shandong Joint Fund for Marine Science Research Centers (U1606403), Financially supported by the Marine S\&T Fund of Shandong Province for Pilot National Laboratory for Marine Science and Technology (Qingdao) (2018SDKJ0401-2), Taishan Scholar Youth Expert Program in Shandong Province (tsqn201812021).

Acknowledgments: The authors recognize material contributions from Prof. Yi Tang (University of California, Los Angeles) for providing plasmids.

Conflicts of Interest: The authors declare no conflict of interest. 


\section{References}

1. Brakhage, A.A.; Schuemann, J.; Bergmann, S.; Scherlach, K.; Schroeckh, V.; Hertweck, C. Activation of fungal silent gene clusters: A new avenue to drug discovery. Prog. Drug Res. 2008, 66, 3-12. [CrossRef]

2. Netzker, T.; Fischer, J.; Weber, J.; Mattern, D.J.; König, C.C.; Valiante, V.; Schroeckh, V.; Brakhage, A.A. Microbial communication leading to the activation of silent fungal secondary metabolite gene clusters. Front. Microbiol. 2015, 6, 299. [CrossRef] [PubMed]

3. Rutledge, P.J.; Challis, G.L. Discovery of microbial natural products by activation of silent biosynthetic gene clusters. Nat. Rev. Microbiol. 2015, 13, 509-523. [CrossRef] [PubMed]

4. Bok, J.W.; Keller, N.P. LaeA, a Regulator of Secondary Metabolism in Aspergillus spp. Eukaryot. Cell 2004, 3, 527-535. [CrossRef] [PubMed]

5. Lee, S.S.; Lee, J.H.; Lee, I. Strain improvement by overexpression of the laeA gene in Monascus pilosus for the production of monascus-fermented rice. J. Microbiol. Biotechnol. 2013, 23, 959-965. [CrossRef] [PubMed]

6. Hong, E.J.; Kim, N.K.; Lee, D.; Kim, W.G.; Lee, I. Overexpression of the laeA gene leads to increased production of cyclopiazonic acid in Aspergillus fumisynnematus. Fungal Biol. 2015, 119, 973-983. [CrossRef] [PubMed]

7. Linde, T.; Zoglowek, M.; Lubeck, M.; Frisvad, J.C.; Lubeck, P.S. The global regulator LaeA controls production of citric acid and endoglucanases in Aspergillus carbonarius. J. Ind. Microbiol. Biot. 2016, 43, 1139-1147. [CrossRef] [PubMed]

8. Chettri, P.; Bradshaw, R.E. LaeA negatively regulates dothistromin production in the pine needle pathogen Dothistroma septosporum. Fungal Genet. Biol. 2016, 97, 24-32. [CrossRef] [PubMed]

9. Jiang, T.; Wang, M.; Li, L.; Si, J.; Song, B.; Zhou, C.; Yu, M.; Wang, X.; Zhang, Y.; Ding, G.; et al. Overexpression of the Global Regulator LaeA in Chaetomium globosum Leads to the Biosynthesis of Chaetoglobosin, Z.J. Nat. Prod. 2016, 79, 2487-2494. [CrossRef]

10. Kosalkova, K.; Garcia-Estrada, C.; Ullan, R.V.; Godio, R.P.; Feltrer, R.; Teijeira, F.; Mauriz, E.; Martin, J.F. The global regulator LaeA controls penicillin biosynthesis, pigmentation and sporulation, but not roquefortine C synthesis in Penicillium chrysogenum. Biochimie 2009, 91, 214-225. [CrossRef]

11. Liu, Q.; Cai, L.; Shao, Y.; Zhou, Y.; Li, M.; Wang, X.; Chen, F. Inactivation of the global regulator LaeA in Monascus ruber results in a species-dependent response in sporulation and secondary metabolism. Fungal Biol. 2016, 120, 297-305. [CrossRef] [PubMed]

12. Estiarte, N.; Lawrence, C.B.; Sanchis, V.; Ramos, A.J.; Crespo-Sempere, A. LaeA and VeA are involved in growth morphology, asexual development, and mycotoxin production in Alternaria alternata. Int. J. Food Microbiol. 2016, 238, 153-164. [CrossRef] [PubMed]

13. Keller, N.P.; Turner, G.; Bennett, J.W. Fungal secondary metabolism-From biochemistry to genomics. Nat. Rev. Microbiol. 2005, 3, 937-947. [CrossRef] [PubMed]

14. Bok, J.W.; Noordermeer, D.; Kale, S.P.; Keller, N.P. Secondary metabolic gene cluster silencing in Aspergillus nidulans. Mol. Microbiol. 2006, 61, 1636-1645. [CrossRef] [PubMed]

15. Xu, Z.C.; Sun, C.; Xu, J.; Zhang, X.; Luo, H.M.; Ji, A.J.; Hu, Y.L.; Song, J.Y.; Chen, S.L. Progress in the study of Velvet and LaeA proteins and their relation to the development and bioactive compounds in medicinal fungi. Yao Хиe Хие Bao 2014, 49, 1520-1527. [PubMed]

16. Abe, N.; Murata, T.; Hirota, A. Novel oxidized sorbicillin dimers with 1,1-diphenyl-2-picrylhydrazyl-radical scavenging activity from a fungus. Biosci. Biotechnol. Biochem. 1998, 62, 2120-2126. [CrossRef] [PubMed]

17. Andrade, R.; Ayer, W.A.; Trifonov, L.S. The metabolites of Trichoderma Longibrachiatum. III. Two new tetronic acids: 5-hydroxyvertinolide and bislongiquinolide. Aust. J. Chem. 1997, 50, 255-257. [CrossRef]

18. Shirota, O.; Pathak, V.; Hossain, C.F.; Sekita, S.; Takatori, K.; Satake, M. Structural elucidation of trichotetronines: Polyketides possessing a bicyclo[2.2.2]octane skeleton with tetronic acid moiety isolated from Trichoderma sp. J. Chem. Soc. Perkin Trans. 1997, 29, 2961-2964. [CrossRef]

19. Evidente, A.; Andolfi, A.; Cimmino, A.; Ganassi, S.; Altomare, C.; Favilla, M.; Cristofaro, A.D.; Vitagliano, S.; Sabatini, M.A. Bisorbicillinoids Produced by the Fungus Trichoderma Citrinoviride Affect Feeding Preference of the Aphid Schizaphis Graminum. J. Chem. Ecol. 2009, 35, 533-541. [CrossRef] 
20. Du, L.; Zhu, T.; Li, L.; Cai, S.; Zhao, B.; Gu, Q. Cytotoxic sorbicillinoids and bisorbicillinoids from a marine-derived fungus Trichoderma sp. Chem. Pharm. Bull. 2009, 57, 220-223. [CrossRef]

21. Trifonov, L.S.; Bieri, J.H.; Prewo, R.; Dreiding, A.S.; Hoesch, L.; Rast, D.M. Isolation and structure elucidation of three metabolites from Verticillium intertextum: Sorbicillin, dihydrosorbicillin and bisvertinoquinol. Tetrahedron 1983, 39, 4243-4256. [CrossRef]

22. Maskey, R.P.; Grün-Wollny, I.; Laatsch, H. Sorbicillin analogues and related dimeric compounds from Penicillium Notatum. J. Nat. Prod. 2005, 68, 865-870. [CrossRef]

23. Balde, E.S.; Andolfi, A.; Bruyère, C.; Cimmino, A.; Lamoral-Theys, D.; Vurro, M.; Damme, M.V.; Altomare, C.; Mathieu, V.; Kiss, R.; et al. Investigations of fungal secondary metabolites with potential anticancer activity. J. Nat. Prod. 2010, 73, 969. [CrossRef]

24. Harned, A.M.; Volp, K.A. The sorbicillinoid family of natural products: Isolation, biosynthesis, and synthetic studies. Nat. Prod. Rep. 2011, 28, 1790. [CrossRef]

25. Tang, M.C.; Cui, X.; He, X.; Ding, Z.; Zhu, T.; Tang, Y.; Li, D. Late-Stage Terpene Cyclization by an Integral Membrane Cyclase in the Biosynthesis of Isoprenoid Epoxycyclohexenone Natural Products. Org. Lett. 2017, 19, 5376-5379. [CrossRef]

26. Yu, G.; Wu, G.; Sun, Z.; Zhang, X.; Che, Q.; Gu, Q.; Zhu, T.; Li, D.; Zhang, G. Cytotoxic Tetrahydroxanthone Dimers from the Mangrove-Associated Fungus Aspergillus versicolor HDN1009. Mar. Drugs 2018, 16, 335. [CrossRef]

27. Larkin, M.A.; Blackshields, G.; Brown, N.P.; Chenna, R.; McGettigan, P.A.; McWilliam, H.; Valentin, F.; Wallace, I.M.; Wilm, A.; Lopez, R.; et al. Clustal W and Clustal X version 2.0. Bioinformatics 2007, 23, 2947-2948. [CrossRef]

28. Kumar, S.; Stecher, G.; Tamura, K. Molecular Evolutionary Genetics Analysis Version 7.0 for bigger datasets. Mol. Biol. Evol. 2016, 33, 1870-1874. [CrossRef]

29. Mitchell, A.L.; Attwood, T.K.; Babbitt, P.C.; Blum, M.; Bork, P.; Bridge, A.; Brown, S.D.; Chang, H.Y.; El-Gebali, S.; Fraser, M.I.; et al. InterPro in 2019: Improving coverage, classification and access to protein sequence annotations. Nucleic Acids Res. 2019, 47, 351-360. [CrossRef]

30. Ohashi, M.; Liu, F.; Hai, Y.; Chen, M.; Tang, M.C.; Yang, Z.; Sato, M.; Watanabe, K.; Houk, K.N.; Tang, Y. SAM-dependent enzyme-catalysed pericyclic reactions in natural product biosynthesis. Nature 2017, 549, 502-506. [CrossRef]

31. Zhang, Z.; He, X.; Che, Q.; Zhang, G.; Zhu, T.; Gu, Q.; Li, D. Sorbicillasins A-B and Scirpyrone K from a Deep-Sea-Derived Fungus, Phialocephala sp. FL30r. Mar. Drugs 2018, 16, 245. [CrossRef]

32. Schwyn, B.; Neilands, J.B. Universal chemical assay for the detection and determination of siderophores. Anal. Biochem. 1987, 160, 47-60. [CrossRef]

33. Jang, J.H.; Kanoh, K.; Adachi, K.; Matsuda, S.; Shizuri, Y. Tenacibactins a-d, hydroxamate siderophores from a marine-derived bacterium, Tenacibaculum sp. a4k-17. J. Nat. Prod. 2007, 70, 563-566. [CrossRef] 